\title{
Names on maps as an element of the discussion about relativism in the understanding of national identity (based on the example of western and northern Polish territories after 1945 and 1989)
}

\begin{abstract}
The article tackles the difficult problem of identity creation of new inhabitants of western and northern Poland after 1945 and of relativism in the understanding of national identity after 1989. One of the manifestations are geographical names, which are reflected on maps. The authors of the article looked at this difficult, historically unprecedented process of integration and identification of new inhabitants with the geographical space through the prism of maps, entering into the contemporary discussion about the transformations taking place in the understanding of national identity.
\end{abstract}

Keywords: western and northern Poland, post-war period, maps, geographical names, identity, relativism

\section{Introduction}

There are many aspects to national identity. Nowadays, two dominant directions determine the content of the discussion on various ways of understanding this concept. The first includes changes in the culture and mentality of societies, taking place on the basis of globalization processes, in which the development of tourism played an unprecedented role. Identity has become a commodity, obsessively preferred and desired by tourists and supplied by local communities.

The second direction is related to tendencies contrary to the phenomena of globalization - a strong attachment to ethnic values, especially visible in areas where the minority national groups not only defend their identification but also propagate it openly.

In the field, traces of identity are usually sought in infrastructure projects, local relations with visitors or geographic nomenclature, using examples of events taking place in different historical time and space. The condition, however, is the existence of this identity. It was more difficult to carry out such analysis in places where identity was just being created, for example as a result of total population replacement done for political reasons after the end of the Second World War, which happened to areas incorporated into Poland. Locals who were ethnically and culturally different from the previous population were transferred to the acquired areas. A process of the newcomers "getting accustomed" to space and the existing heritage, adapting them to live in new conditions and building new ties was launched. This phenomenon is illustrated by numerous publications appearing in the immediate post-war period, both historical research papers and tourist guides covering the new areas (F. Czarnecki 1962), and the creation of the native, friendly image of these lands became quite a political and social challenge, extensively utilising 
the symbolic function of names, consisting in reinforcing one version or history and suppressing another (A. Czerny 2011, p. 102) ${ }^{1}$. Such a situation occurred in the first years after the Second World War, not only in the areas of western and northern Poland but also in the USSR in the Kaliningrad district and in Czechoslovakia in Zaolzie region. Norman Davies wrote (2014) that the key to Eastern European geographical names lies in the ability to assign to each name the appropriate context - temporal, geographic and political.

The authors of the article set themselves the goal of tracing the process of building national identity in the areas annexed to Poland in the politically unstable early post-war years and the evolution of this concept in a culturally and mentally "fluid" post-transformation period, that is after 1989, based on geographical names, mainly on maps depicting these areas. They assumed that the basic determinant of identity is identification with the terrain and the accompanying system of values, and one of the manifestations are geographical names, which are reflected in the marking on the ground and on maps.

The article also attempts to achieve two specific objectives. The first explains the importance of maps in the process of merging Polish territories in the second half of the 1940s and underlines the role of geographical names in this political and social undertaking aimed at the shaping of the identity. The second points to the fact that the identity and the accompanying values are not given once and for all, each time their scope and content are verified by the present.

In achieving the research goals, the authors used the unprecedented process of population replacement in Eastern Europe immediately after the Second World War. Therefore, selected maps from 1945-1948, which were addressed to the population arriving in the discussed areas, became the subject of the source analysis. On the one hand, the year 1948 saw the completion of the basic phase of settling the Western

\footnotetext{
${ }^{1}$ Writing about the political motives behind name changes, the author quotes, among others, J. Pospelov's work Nazvanija gorodov i sël, published in Moscow in 1996, in which removing historical names is called "memory obliteration" in view of the new political conditions under which this nam eis unacceptable.
}

and Northern Lands of Poland (about 5 million new inhabitants), on the other hand, it ended to a large extent (though not definitively) the period of work on the Polish geographical names in the new territories. The Commission on Establishing the Place Names, and since 1948 the Commission on Establishing the Names of Localities and Physiographic Objects at the Ministry of Public Administration ceased its activity in 1958, publishing its latest findings.

The maps appearing on the Polish publishing market from the mid-nineties of the twentieth century were used to illustrate changes in the understanding of national identity. They included both phenomena related to the commercialization of identity and the restoration of its national values.

\section{Analysis of research material in the context of political change}

The process of settling western and northern Poland within the borders after the Second World War was carried out most dynamically in the years 1945-1947. The arriving population was an extremely colourful cultural mosaic because these people came from various territories. Generally, it was made up of four basic groups: Polish population with native roots, repatriates from beyond the new eastern border of Poland, re-emigrants from other countries and displaced persons. The settlers faced tasks of historical importance: creating a local community, aware of its place and role; merging these lands with the rest of the country, finding a way to stay and develop; determining the attitude to the past and to their German neighbours (R. Domke 2010). Regarding the last aspect, the new authorities did not hide their hostility towards the Germans, and "an unusual crusade for the Polishness of the western and northern lands" became the raison d'etat (A. Czerny 2011, p. 293).

Giving the incorporated lands Polish geographical names in line with the demands of the government as well as the population became a matter of great urgency for the assimilation and integration processes. It was done by eminent linguists and geographers, gathered in various decision-making and opinion-forming bodies. The earliest, significant contribution was provided by the Instytut Zachodni (Western 
Institute) in Poznań, where in 1945 a special Onomastic Section was set up. According to J. Ostrowski (2010), Polish names on maps were decided gradually by the Commission on Establishing Place Names, reactivated in 1945, and since 1948 by the Commission on Establishing the Names of Localities and Physiographic Objects. The appointment of this commission allowed the co-ordination of work, which greatly accelerated the process of Polonisation itself, and the "Polish-Slavonic tenor of all names in the new lands was considered one of the basic attributes of Polish domination over them, a demonstrative argument for the rest of the world, but also an element for creating a sense of familiarity in the population of settlers arriving in these areas" (G. Strauchold 2010, p. 25).

At that time, maps used as a tool of space imaging reflected the current state in terms of naming arrangements and fulfilled a propaganda function. Those earliest, dating from 1945-1946, revealed the lack of final solutions in this area. This is perfectly illustrated by a auto map of Lower Silesia from 1945 (fig. 1). In the absence of the western border, a network of roads formed peculiar connections. For this purpose, references were made to historical Polish and Lusatian geographical names, e.g. Chociebuż, Barść, Mużaków, and therefore it can be seen that these were intra-Slavonic connections. The distinctive dislike of the German names was accompanied by the simultaneous certainty that regardless of the ultimate course of this border, it would always be Slav-friendly.
Similar, though ideologically different border-naming problems were shown on the map of Eastern Pomerania elaborated by J. Szaflarski (Bydgoszcz 1945) and on the map of the Mazurian District, drawn up by M. Kiełczewska and W. Chojnacki (Poznań 1946) (fig. 2). While in the case of the former map the lack of marking the border from the north did not seem acute - after all, the neighbour was Poland's great ally - the Soviet Union, in the case of the latter, there are noticeable connotations and historical sentiments in reference to Polish names, e.g. Królewiec (Königsberg, from June 1946 Kaliningrad, Wystruć (Insterburg, from 1946 Chernyakhovsk). In the vast majority of today's Warmia and Mazury, double names were used - Polish and German. In the absence of the definitive adoption of new names, this solution provided faster orientation in the field.

In the Jelenia Góra guide published in 1946, one can find a common justification for this: "The names of the locality are often given in three language versions: in the one that the Polish local population has already got used to [...] then the one established by the Commission on Establishing the Place Names and finally, the old German names for orientation, the more so because in the absence of detailed Polish maps, tourists use German maps for the time being." (J. Sykulski 1946, p. 46).

The next stage of the integration processes is reflected in a map of railway connections in Lower Silesia from 1946 (fig. 3). The political and administrative boundaries had already been

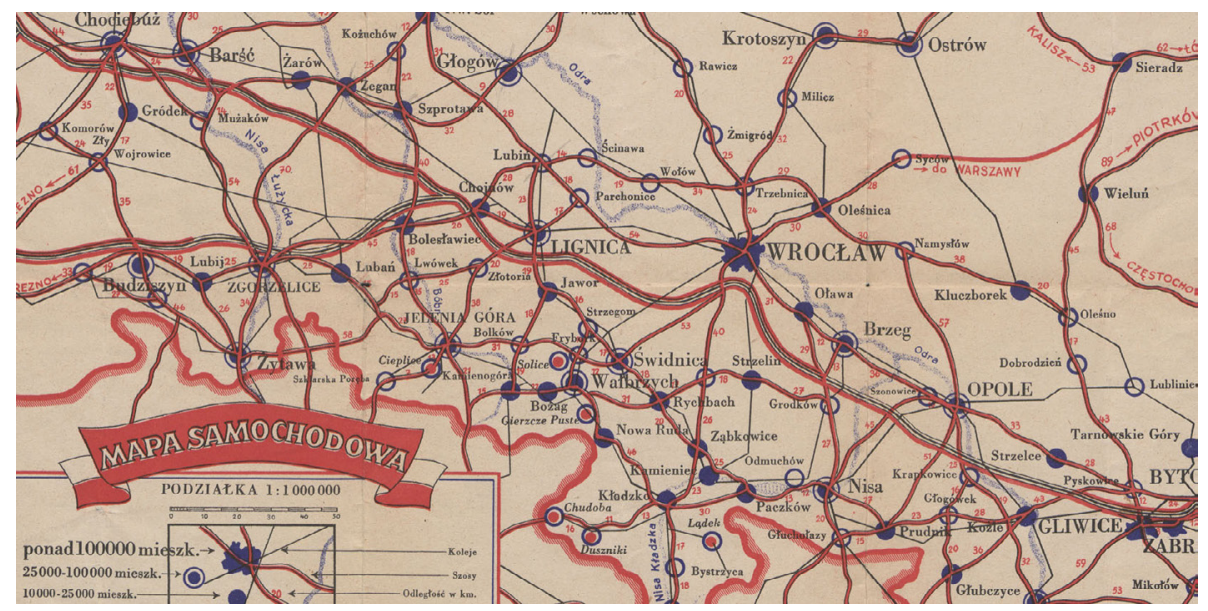

Fig. 1. Part of a map Dolny Śląsk. Mapa samochodowa, 1:1,000,000, 1945 




Fig. 2. Part of a map Okręg Mazurski. Mapa komunikacyjno-administracyjna, 1:500,000, 1946

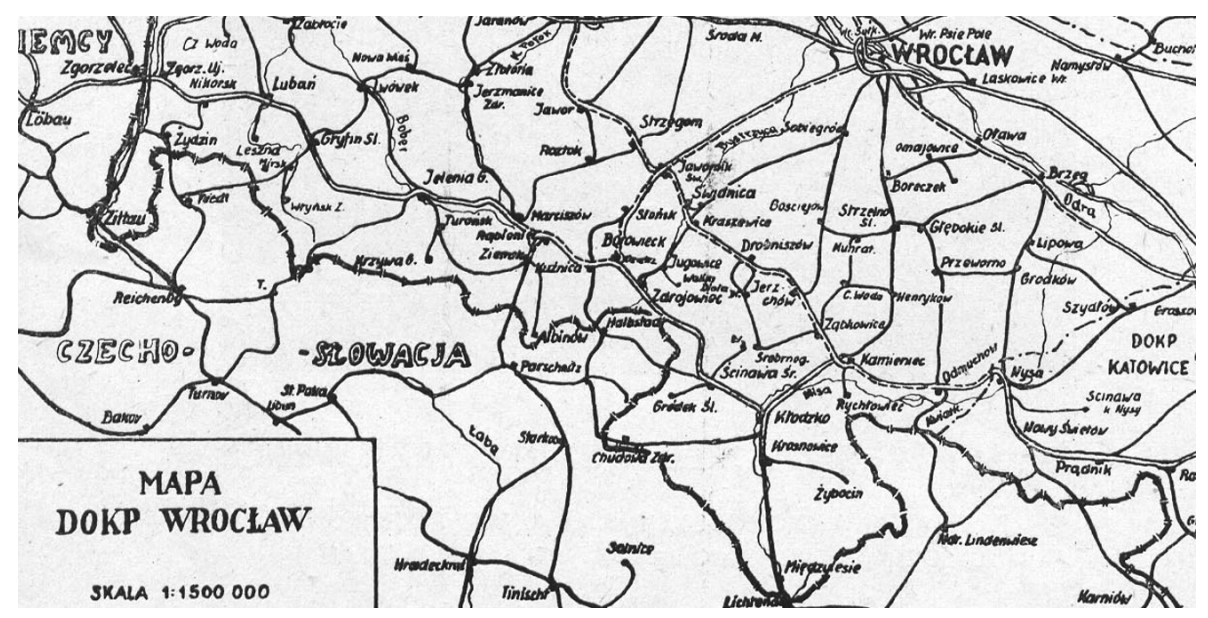

Fig. 3. Part of Mapa DOKP Wrocław, 1:1,500,000, 1946

delimited, while the problem of incorporating the region into the network of the Polskie Koleje Państwowe (Polish State Railways) remained. Connections in the analyzed areas up to 1945 were oriented to other directions (west, north-west, south), hence the importance of highlighting new priority links on this map: with Poznań, Łódź, and Katowice. Most of the towns on the map have already received new names, but the name of Zgorzelec (instead of Görlitz) on the German side and the German Zittau (instead of Żytawa) on the Polish side indicates that the names were still very unstable at that time.

\section{Map analysis in the aspect of restoring national heritage}

Although they were not the authors of the geographical names in the newly incorporated areas of Poland, cartographers did play a very important role. On the one hand, their maps reflected the current status of work in this respect, and on the other hand, they highlighted the magnitude of the problems that had to be dealt with, which sometimes led to onomastic chaos. Maps from 1945-1948 also allow distinguish- 
ing the stages of work on the new nomenclature, show successive steps towards the final decisions. Maps were the most spectacular form of communication and at the same time a proof of cultural changes in the analysed area. An example of such approach, building a symbolic national identity, is the propaganda map of Lower Silesia from 1946 printed against the background of the Polish eagle (fig. 4). perspective - restoring the obliterated memory and reconstructing the heritage.

One of the difficulties encountered by the cartographers was the use of various sources. In the absence of top-down arrangements, names from old publications were used. One of them was Słownik geograficzny Królestwa Polskiego i innych krajów słowiańskich (Geographical vocabulary of the Polish Kingdom and

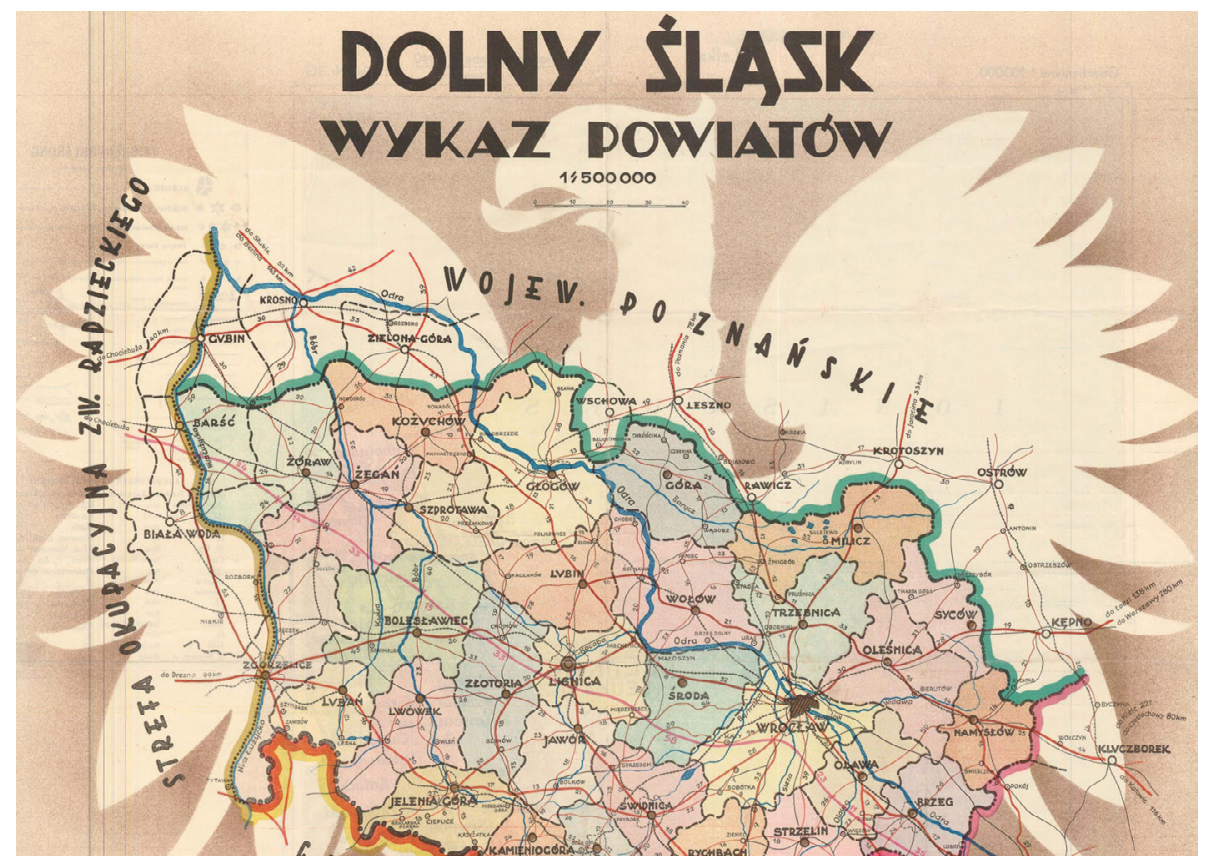

Fig. 4. Part of a map Dolny Śląsk. Wykaz powiatów, 1:500,000, 1946

Work on naming the analyzed lands required a multilateral approach: linguistic, historical, geographical, practical and legal-organizational. From the point of view of taming the historical landscape, the most attention was paid to language and historical issues. The names were compared to the external landscape, paying attention to the purity and aesthetics of this aspect (I. Lewandowska 2010). Linguists, whose duty was to protect the mother tongue from contamination by foreign influences, were seen as guardians of terminological purity (K. Kolańczyk 1946). There was, however, yet another, deeper objective - obliterating any traces of the presence of other ethnic groups and, in a longer other Slavic countries), published in the years 1880-1902, as in the case of the maps shown above. References were also made to local traditions and expert advice was used. On a part of the map developed by Maria Kiełczewska and published by the Instytut Zachodni in Poznań in 1945 , there are differences in the spelling of names, e.g. Chociebuż - Chociebórz; Barść Barszcz (fig. 5).

Another problem was that there existed no original Polish maps for these areas, and German maps with pre-war administrative divisions were used for their elaboration. This was also reflected in the nomenclature, especially in the earliest period. An interesting example of "ren- 


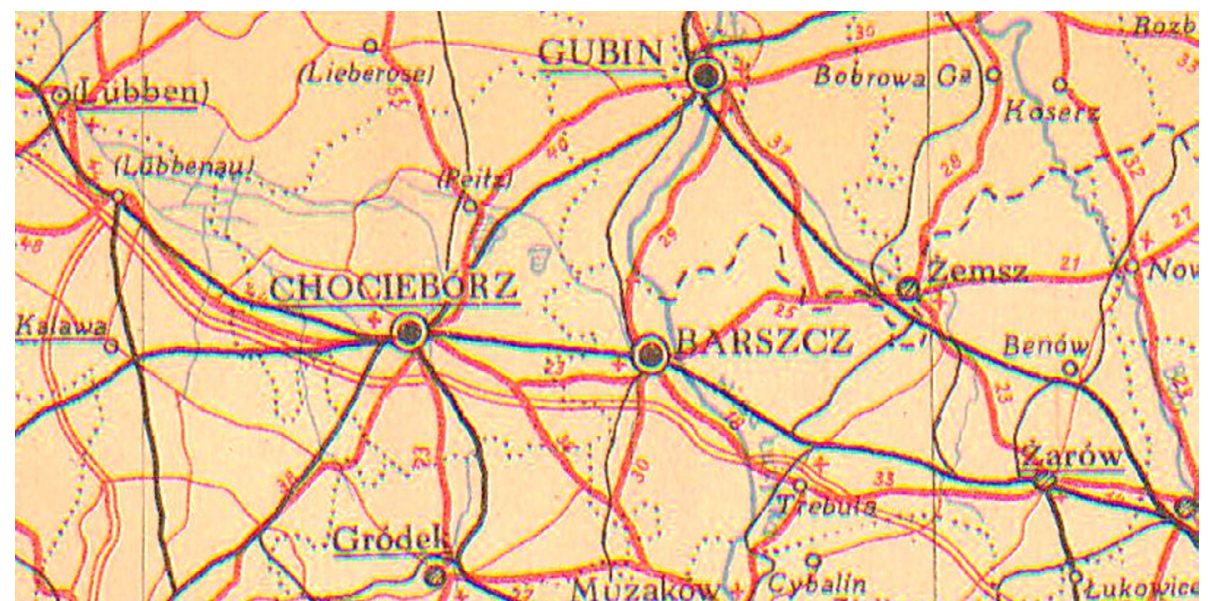

Fig. 5. Part of Polska Zachodnia. Mapa komunikacyjno-administracyjna, 1:1,000,000, 1945

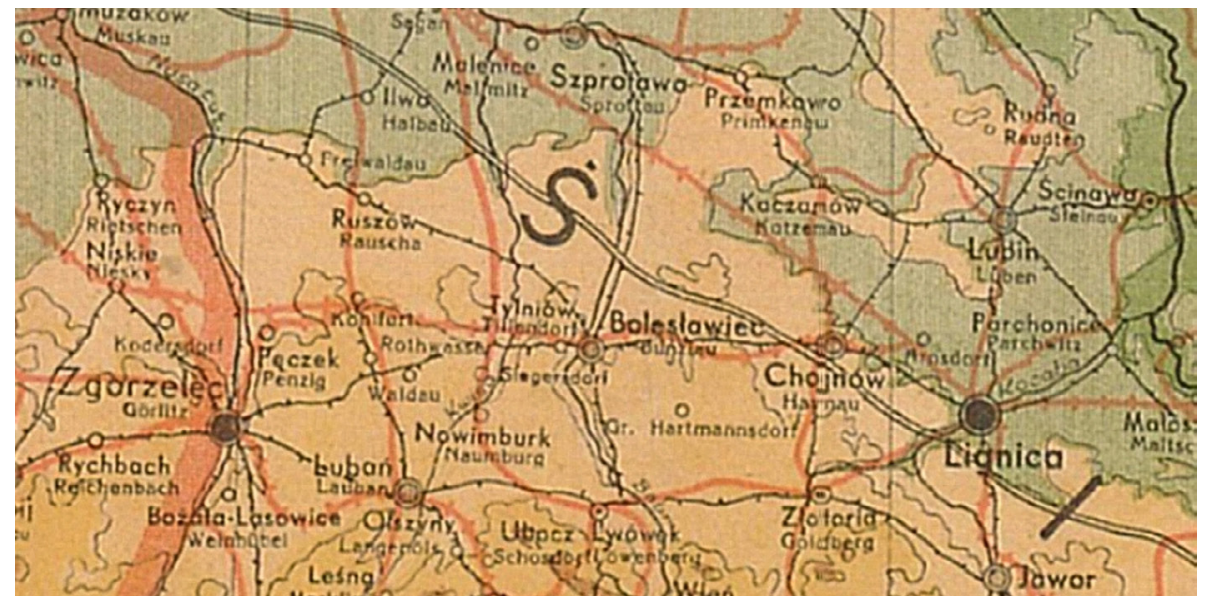

Fig. 6. Part of a map Polskie Ziemie Zachodnie i Pomorze Wschodnie, 1:1,250,000, 1945

dering the alien familiar" is provided by the map elaborated by J. Szaflarski (fig. 6), where we can see three versions of names: only Polish, Polish and German and modified to Polish (Slavic). One example of this is today's Nowogrodziec, which on the map is described as Nowimburk. The German name Naumburg functioned in its Slavic form back in the 19th century (J. Mycielski 1900) by introducing the particle "Nowim" and changing the last letter " $g$ " to " $k$ ", which turned the name into a familiar-sounding word. This name was also used in a map of Poland published in 1945 by the Military Geographical Institute.
On the map of Silesia elaborated by J. Szaflarski and A. Wrzosek, in turn, there was a clash of two identities. The area of the pre-war Silesian Voivodship was clearly separated by a dotted line, denoting its former boundaries, and received a lighter coloured backdrop. The duality of the region's image is emphasized by the double names in the new areas and only Polish names in the former voivodship. In this case, there are doubts whether this was conducive to building a cultural commonwealth quickly.

On the maps of the incorporated area published in the years 1947-1948, one can see how solving onomastic problems entered the 
final phase when only the official Polish names (approved by the Commission) and those used by the settlers were placed on the maps. This meant the end of the phase where the German names were still allowed. This approach, using two names in one language, seems natural in the light of the interpretation proposed by A. Czerny (2011). He stated that by standardizing the geographical names from among two or more alonyms (by-forms), if possible, only one preferred name is chosen. While the uniqueness of all names is unattainable in practice, assigning to each place (e.g. every town in the territory of the country) exactly one standardised name can be done.

\section{Map analysis as an image of identity relativism}

The departure from the centrally controlled economy model to the market economy model, as a result of political and systemic transformations in the former Eastern bloc, also opened new opportunities for economic and civilization development to Poland. The globalization mentioned in the Introduction has increased the mobility of societies. Tourists from various directions started coming to Poland. The areas of tourist penetration included, among others, western and northern territories, which became the destination for their former inhabitants or their descendants as part of the so-called sentimental tourism. Cartography firms decided to meet the needs of these customers. In 1991 Polskie Przedsiębiorstwo Wydawnictw Kartograficznych (Polish Cartographical Publishing House) issued a tourist map Wielkie Jeziora Mazurskie (Great Mazurian Lakes), which three years later appeared with names in two languages, Polish and German. Another map, showing the 1939 borders, was prepared by Demart (2008) and a State publisher, the Head Office of Geodesy and Cartography. These examples demonstrate the relativism in the approach to national identity; they show how, under different political conditions, one can share the identity while showing respect for former inhabitants, how it can be commercialized. Today, in the era of cultural and mental changes related to the processes of globalization and market play, nobody is shocked by such facts, and examples of research show that nowadays identity is also a commodity (M.K. Leniartek,
K. Widawski 2012). One could say that new contents have been added to the identity of these lands and its image modified.

Different reasons caused the appearance of double, Polish and German geographical names on maps of the Opole region after 1989. Although the post-war State policy resulted the the same type of Polonisation of the incorporated territories, the most numerous German minority, today accounting for over $20 \%$ of the total population, survives in the Opole Silesia (M. Zych 2014). Following the political changes and the opening of Poland to Western cultural values, on 1 May 2005 the Act on National and Ethnical Minorities and Regional Language was adopted. Under this law, German has become an auxiliary language in 28 communes in Opolskie Voivodship (fig. 7). Together with three communes in Silesian Voivodship, this currently amounts to 359 additional German names of towns and villages (Komisja Standaryzacji... 2016). These names appeared not just on maps, but also in the field.

The example of Opolskie Voivodship demonstrates that it is impossible to manage the process of shaping the national identity by superior authority, and the geographical name in the native tongue, acting as an identifier of

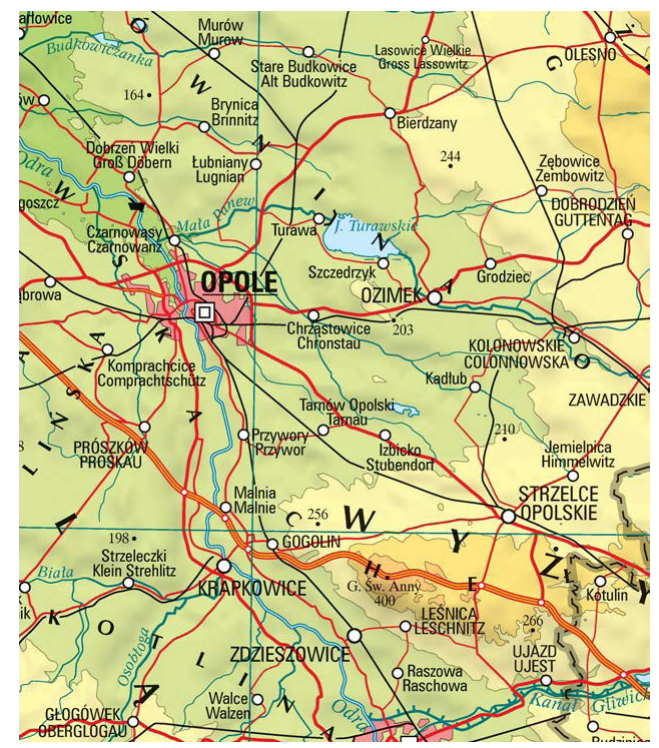

Fig. 7. Part of a map of Poland with additional German names, 2011 
territorial awareness, will always be an indicator of the ethnicity of the local population.

\section{Conclusions}

The subject of this article forms part of an academic discussion on the relativism of identity, concerning the relationship between the geographical name and identity (national, regional, local) and the role of geographical names in building and sustaining community awareness, defined by space. According to A. Czerny (2011), the traditional approach to geographical names treated them as passive artefacts written in documents and maps, being a testimony of the past and allowing reconstructing the old landscape, while a new research direction treats names as an important component of the landscape, present materially in the daily life of people. These researchers bring to the fore the role of names in the processes of constructing heritage and collective identity. According to them, names create symbolic texts which are components of whole systems of meanings and ideologies affecting society.

The approach to geographical names as a source of knowledge about the shaping of identity processes in a different dimension, including the national one, inspired the authors of the article to take a broader look at the problems and phenomena occurring in the northern and western Polish territories after 1945. Earlier, they focused on tourism as an area of the economy having a significant impact on the level of territorial awareness (T. Bogacz, B. Konopska 2012). However, this rather narrow approach did not allow the authors to discuss many other, equally important aspects accompanying the

\section{Literature}

Bogacz T., Konopska B., 2012, Meandry tożsamości w świetle nazewnictwa na powojennych mapach turystycznych Ziem Zachodnich i Północnych Polski. In: Nasze i nienasze w turystyce. Ed. M.K. Leniartek. Wrocław: WSZ „Edukacja”, pp. 297-316.

Czarnecki F., 1962, Bibliografia Ziem Zachodnich 1945-1958, Poznań: Instytut Zachodni.

Czerny A., 2011, Teoria nazw geograficznych. „Prace Geograficzne” nr 226. Warszawa: Instytut Geografii i Przestrzennego Zagospodarowania PAN.

Davis N., 2014, Serce Europy: Polska: przeszłość we współczesności. Polish transl. E. Tabakowska, Kraków: Wydawnictwo Znak. research on mental changes of the inhabitants of these lands.

The analysis of selected maps in terms of geographical names allows formulating several conclusions and observations. Two stages of the integration process are clearly visible: 1) 1945-1946 (launch of the Commission on Establishing the Place Names and 2) 1947-1948 (domination of names sounding Polish or Slavic, especially in Western Lands).

The process of shaping identity in the western and northern territories of Poland was the reverse of this type of processes in other areas - top-down, not bottom-up. Hence, national and not regional awareness was the first stage of identification.

Maps from the immediate post-war years reflect, on the one hand, the implementation of political and propaganda directives imposed by the State, and on the other hand, one can see in them the dilemmas and even some "insubordination" on the part of their authors. This resulted to a large extent from the prolonged work on the final naming arrangements.

The analysis of the maps published after the political transformation revealed the ethnic identity of a large part of the population, inhabiting the incorporated areas, which survived despite unfavourable conditions in the Polish People's Republic (till 1989), as well as in the first years of independence. Only Poland's accession to the European structures allowed the reflection of ethnic diversity, also through the use of dual geographical names.

The relativism of values and the fluidity of concepts in the modern world have also influenced the perception of national identity as a tourist product.
Domke R., 2010, Ziemie Zachodnie i Północne Polski w propagandzie lat 1945-1948. Zielona Góra: Wyd. Uniwersytetu Zielonogórskiego.

Kolańczyk K., 1946, O nazwy polskie na Ziemiach Odzyskanych. „Przegląd Zachodni” R. 2, nr 6, pp. 540-547.

Komisja Standaryzacji Nazw Geograficznych poza Granicami Rzeczypospolitej Polskiej (http://ksng. gugik.gov.pl/nwjmwp.php)

Krasny P., Ziarkowski D. (eds.), 2009, Sztuka i podróżowanie. Studia teoretyczne i historyczno-artystyczne. Kraków: Proksenia. 
Leniartek M.K., Widawski K. (eds.), 2012, Nowa ekonomia turystyki kulturowej. Wrocław: WSZ „Edukacja”.

Lewandowska I., 2010, Oswajanie poniemieckiej przestrzeni nazewniczej na Warmii i Mazurach po Il wojnie światowej. In: Nazwa dokumentem przeszłości regionu. Tom poświęcony Wielkiemu Profesorowi Stanisławowi Rospondowi. Eds. J. Nowosielska-Sobel, G. Strauchold, W. Kucharski. Wrocław, pp. 35-63.

Mycielski J., 1900, Pierwotne słowiańskie nazwiska miejscowości na Śląsku Pruskim. Poznań.

Ostrowski J., 2010, Pierwsze polskie mapy poszczególnych regionów Ziem Zachodnich i Północnych $z$ lat 1945-1948. In: Kartografia w regionie, „Prace i Studia Kartograficzne" T. 2, pp. 74-92.

Toponymic guidelines of Poland for map editors and other users, 2010. Fourth revised edition. Eds. E. Wolnicz-Pawłowska, M. Zych. Commission on Standardization of Geographical Names outside the Republic of Poland affiliated to the Surveyor General of Poland. Warsaw: Head Office of Geodesy and Cartography.

Strauchold G., 2010, Dyskusja wokół polskiego nazewnictwa tzw. Ziem Odzyskanych w latach 40. XXw. In: Nazwa dokumentem przeszłości regionu. Tom poświęcony Wielkiemu Profesorowi Stanisławowi Rospondowi. Eds. J. Nowosielska-Sobel, G. Strauchold, W. Kucharski. Wrocław, pp. 21-34.

Sykulski J., 1946, Ilustrowany przewodnik po JeIeniej Górze i okolicy. Jelenia Góra: Księgarnia Oświata.

Zych M., 2014, Nazwy w językach mniejszości w Polsce. Komisja Standaryzacji Nazw poza granicami Rzeczypospolitej Polskiej przy GUGiK http://www.stagn.de/SharedDocs/Downloads/DE/ StAGN_Publikationen/StAGN_135/06_Zych.pdf? blob=publicationFile\&v $=7$ (access 10.01.2018)

\section{Cartographic sources}

Autokarte Polen (Auto map of Poland), Masstab 1:750,000. Warszawa: Demart SA, 2008.

Dolny Śląsk. Wykaz powiatów (Lower Silesia. List of counties), 1:500,000. Elab. A. Faliński, Wrocław: Nakładem Wojewódzkiego Urzędu Informacji i Propagandy, 1946.

Dolny Śląsk. Mapa samochodowa (Lower Silesia. Auto map), 1:1,000,000. Wrocław: Urząd Informacji i Propagandy, 1945.

Mapa Polski. Warszawa: Główny Urząd Geodezji i Kartografii, source: http://www.stagn.de/SharedDocs/ Downloads/DE/StAGN_Publikationen/StAGN_ 135/06_Zych.pdf?_blob=publicationFile\&v=7 (access 10.01.2018)

Mapa DOKP Wrocław (Map of DOKP Wrocław), 1:1,500,000, inserted in PKP na Dolnym Śląsku, Wrocław 1946, p. 102 (text figure).

Okręg Mazurski. Mapa komunikacyjno-administracyjna (Mazurian District. Communication and administration map), 1:500,000. Elab. M. Kiełczewska and Wł. Chojnacki. Poznań: Wydawnictwo Instytutu Zachodniego, 1946.

Polska Zachodnia. Mapa komunikacyjno-administracyjna (Western Poland. Communication and administration map), 1:1,000,000. Elab. M. Kiełczewska. Poznań: Wydawnictwo Instytutu Zachodniego, 1945.

Polskie Ziemie Zachodnie i Pomorze Wschodnie (Polish Western Lands and Eastern Pomerania), 1:1,250,000. Elab. J. Szaflarski. Kraków: Wydawnictwo Polskiego Związku Zachodniego, 1945.

Śląsk. Mapa fizyczno-administracyjna (Silesia. Phisical and administrative map), 1:500,000. Elab. J. Szaflarski and A. Wrzosek. Katowice: Wydawnictwo Instytutu Śląskiego, 1945.

Wielkie Jeziora Mazurskie (Great Masurian Lakes), 1:100,000. Warszawa: PPWK S.A., 1994. 